
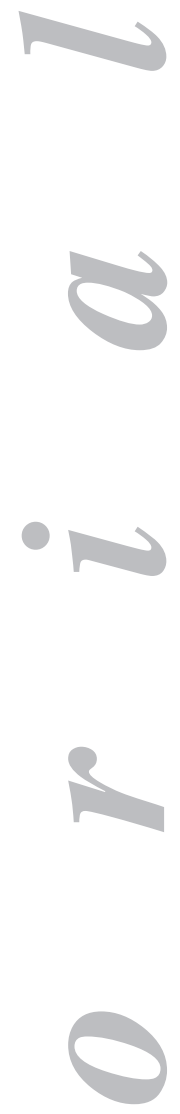

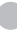
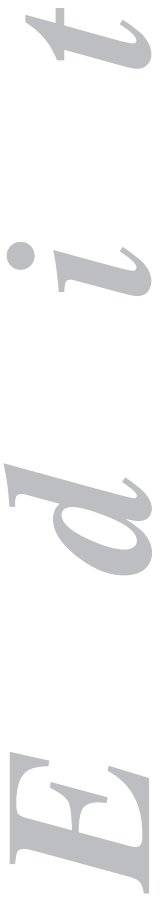

\section{Infliximab in Crohn's disease}

Infliximab (IFX) is a chimeric monoclonal antibody (75\% human/25\% mouse) belonging to the IgG-1 class that is intended to specifically block cell receptors, as well as circulating TNF $\alpha$, a Th-1 response cytokine with marked proinflammatory activity. Hence, the administration of IFX (Remicade ${ }^{\circledR}$, Centocor, Malvern, PA; ScheringPlough, Kenilworth, NJ, USA), a novel biological therapy, results in a marked, powerful, mainly anti-inflammatory therapeutic effect in receiving subjects (1).

Clearly established indications for its use in Crohn's disease (CD) include the management of moderate to severe inflammatory flare-ups, and patients with associated fistulas; its clinical administration received U.S. FDA approval in October 1998 , and its use has notably spread worldwide ever since $(2,3)$. IFX is not indicated in the presence of fibrous stenosis (relative contraindication), or in patients with associated extraintestinal infection (absolute contraindication), regardless of origin (bacterial, viral, fungal) or site.

Various drugs have been commonly used in the treatment of $\mathrm{CD}$ in daily practice for disease acute and chronic stages, in order to prevent recurrent flare-ups from developing.

Drugs considered being first-choice for $\mathrm{CD}$ such as sulfasalazine, aminosalycilates and corticoids are used both to treat acute periods and to prevent relapses. If a patient is unresponsive to these drugs or when either corticoid-dependence or corticoid-refractoriness develops medication is then changed and immunomodulating drugs are selected instead, as a second, long-term therapeutic echelon.

Among drugs belonging to this second group, azathioprine (AZA) or its direct metabolite 6-mercaptopurine (6-MP) and methrotexate (MTX), until then used in the prevention of solid organ rejection for transplanted patients and in the control of autoimmune joint disease such as rheumatoid arthtitis (RA) and ankylosing spondylitis (AS), are most commonly administered.

Overall, both in CD and ulcerative colitis (UC), immunosuppressing drugs have proven highly effective in the clinical setting, with a good safety profile and excellent efficacy in terms of cost-benefit (4-6).

The arrival of infliximab (IFX) in the therapeutic armamentarium as a third-step drug for the control of $\mathrm{CD}$, represents a significant change, as it manages to rapidly and effectively reduce intestinal inflammation on the one hand, and represents the first medical treatment to ever induce fistula closure in the context of this disease on the other hand, which it consistently does in a high percentage of patients (around 60\%).

In 1977 Targan et al. were first to report on a controlled clinical trial of IFX in patients with moderate to severe inflammatory CD flare-ups, with an initial response rate of $81 \%$ at week 4 , following a single intravenous infusion of $5 \mathrm{mg} / \mathrm{kg}$ versus $17 \%$ in the placebo group. Clinical remission was achieved in 33\% of treated pa- 
tients, versus $4 \%$ among those who received placebo. A small proportion of patients who did not respond to the initial infusion did respond to a second dose 4 weeks later (7).

For the treatment of fistula-complicated CD with IFX, where three intravenous infusions at a dosage of $5 \mathrm{mg} / \mathrm{kg}$ were administered in weeks 0,2 , and 6 , Present et al. (8) included in their study 98 patients and found that $62 \%$ responded to IFX versus $26 \%$ amongst those treated with placebo. Of actively treated patients, $55 \%$ attained a complete closure of fistulas versus $13 \%$ of those randomized in the placebo group $(\mathrm{p}=0.001)$.

Following the excitement engendered by results obtained in these early studies a huge proportion of treated patients was seen to relapse within 8-12 weeks after having completed their first therapy course. In contrast, patients receiving IFX recall doses every eight weeks showed significantly prolonged clinical benefits (9).

These results were confirmed by the ACCENT I study, the reported trial with the largest series of patients under IFX maintenance therapy thus far (10). This study included 573 patients with active CD who were administered an initial IFX infusion. During week 2, 58\% of patients showed a good clinical response. Responders were subsequently allocated to three follow-up groups for 54 weeks -a placebo-treated control group, a group with IFX $5 \mathrm{mg} / \mathrm{kg}$ in an endovenous infusion every 8 weeks, and a group receiving a $10 \mathrm{mg} / \mathrm{kg}$ endovenous infusion every 8 weeks. Among patients treated with IFX $5 \mathrm{mg} / \mathrm{kg}$, clinical response was still ongoing by week 30 in around 50\%, and by week 54 in 35\%. Those who received $10 \mathrm{mg} / \mathrm{kg}$ had not improved response rates when compared to subjects receiving $5 \mathrm{mg} / \mathrm{kg}$.

In parallel with other trials, this study has consistently revealed that IFX may induce a relevant, virtually complete reduction of bowel inflammatory lesions, as confirmed by both endoscopic and histologic examination (11).

Regarding its mechanism of action, IFX blocks both circulating soluble TNFa (sTNF) and cell membrane-associated TNF $\alpha$ (mTNF), and may induce apoptosis (programmed cell death) in peripheral blood monocytes using the caspase activation pathway both in patients with CD and healthy individuals. Similarly, IFX administration results in apoptosis in $\mathrm{T}(\mathrm{CD} 4+)$ lymphocytes at the intestinal lamina propria $(12,13)$.

IFX effects are likely different in RA and CD. Soluble TNF $\alpha$ neutralization is its main mechanism of action in the former, whereas in the latter this effect does not suffice, as lymphocyte apoptosis at the bowel's lamina propria is considered of paramount importance for its therapeutic effect. This explains why the administration of etanercept, another monoclonal anti-TNF antibody, is effective in RA -as it neutralizes STNF $\alpha$ - but is not indicated in CD -as it cannot block mTNF $\alpha$ receptors (14).

Several attempts have been made to explain unresponsiveness to IFX observed in $20-30 \%$ of patients, and to unveil potential predictive factors for response, particularly in patients with fistulous CD.

Louis et al. (15) demonstrated that response to IFX therapy was associated with the presence of extensive systemic inflammation, as indirectly measured by high C-reactive protein (CRP) levels. Thus, in a study including 226 patients with $\mathrm{CD}$, response rates were higher among patients with high CRP levels $(>5 \mathrm{mg} / \mathrm{L})$ versus those with normal CRP levels ( 76 versus $46 \%, p=0.004$, OR: 0.26 ), and no relation whatsoever to TNF $\alpha$ polymorphisms such as the high-output, $-308 \mathrm{~A}$ TNF $\alpha$ variant was seen.

The only factor so far reported, that is clearly predictive for response is the concomitant use of immunosuppressors, such as AZA, 6-MP, and MTX $(16,17)$. 
In this issue of our journal, Luna-Chadod et al. analyzed a series of response predictive factors in a series of 108 patients with fistulizing CD within a multicenter study that was carried out in seven hospitals in the Autonomous Region of Madrid, and they found no significant factors associated with response, similarly to other previously reported studies on this topic (18).

Quality of life is pretty impaired in patients with $\mathrm{CD}$, both at the physical and psychological level, with a relevant degree of dysfunction both in its own right and when compared to other chronic conditions. Thus, Gregor et al. found that measurements of health-related quality of life (HQoL) parameters in patients with controlled $\mathrm{CD}$ were similar to those of individuals suffering from severe angina, which is associated with serious labor disability (19).

Various studies have been performed regarding the effect of IFX on HQoL in patients with $\mathrm{CD}$, clearly showing its effectiveness both for acute and long-term maintenance therapy $(20,21)$.

In this issue, Cadahia et al. study the short-term improvement brought about by IFX in a series of 25 patients with fistulous CD using two tests -a general (SF-36) and a specific (IBDQ) test, which they compare to Crohn's disease activity index (CDAI)- along acute management and after 1 month following acute therapy completion. Similarly to other authors, they found a significant improvement in parameters assessing physical function and disease activity, with no noticeable changes in social function, which is better preserved than physical function (22).

Reactions to IFX infusion are thought to develop as a consequence of anti-infliximab antibodies (ATIs) and are a well known complication, their incidence being estimated as $13-18 \%$ of treated patients. They may be both early and late reactions. Regarding immediate reactions, the most common ones consist of mild symptoms such as facial reddening or serious anaphylactic responses such as dyspnea and hypotension. A reduction of the infusion rate suffices in most cases to treat this problem, and infusions may be completed in spite of these reactions, provided they are mild and temporary.

ATI development is on the one hand associated with a more frequent development of infusion reactions with successive doses, and on the other hand with reduced IFX treatment response rates. Concomitant immunosuppressive therapy, previous intravenous hydrocortisone infusions, and shorter intervals between IFX infusions have all been suggested to notably reduce both the frequency and severity of allergic reactions to IFX administration $(23,24)$.

Most common late reactions to IFX infusion include pain and swelling of several joints, which are usually treated with NSAIDs and/or corticoids. The frequency of reactions to IFX infusion, both early and late, is similar in adults and children (25).

Regarding the development of infectious adverse affects, tuberculosis is a wellknown, relevant one. In a review of FDA-provided data on a total of 150,000 patients treated with IFX until March 29, 2001, 70 subjects had developed tuberculosis after a mean therapy course of 12 weeks, and 40 of these had extrapulmonary involvement; most cases were reactivations of a latent, previous disease (26).

In a recently published review in our country, which was performed under the auspices of "Sociedad Española de Reumatología", and which included 71 centers, an estimated incidence of 1.9 per $10^{5}$ was reported for year 2000, which diminished to 1.1 per $10^{5}$ in 2001 . Since the adoption of systematic screening procedures for tuberculosis before IFX therapy onset (routine chest x-rays and PPD test) incidence has noticeably decreased, and only one case has been reported in the first 5 months of 2002, in the study reported by Gómez-Reino et al. (27). 
The safety profile of IFX has been carefully analyzed in an extensive series of 500 patients with $\mathrm{CD}$ who were treated at the Mayo Clinic and received an average of three infusions each, with a mean follow-up of at least 17 months. Six percent of patients treated with this regimen developed a significant side effect, which most commonly included acute infection episodes. Therefore, clinicians treating these patients with this sort of drugs must set up a close monitorization program, so that the development of potential complications -including infection, reactions to infusion, and autoimmune disturbances- may undergo early detection and thus be prevented (28).

As regards the development of potential IFX-related neoplasms it is as yet unknown whether long-term administration of this new biologic therapy may result in an increased incidence of malignancies -both lymphomas and solid tumorsfrom increased immunosuppressive effects brought about by the concomitant use of other drugs (AZT or MTX); such incidence, however, does not seem to be currently increa-sed, and cumulative experience with the use of IFX is now extensive, since around 340,000 patients had already received this drug worldwide by late 2002.

Other indications of IFX treatment are CD-related systemic complications. Thus, in a series of 13 patients who had moderate to severe pyoderma gangrenosum, the administration of IFX resulted in complete skin lesion healing in all patients (29).

However, it looks like IFX administration is not going to be extended for the treatment of patients with ulcerative colitis (UC), since results thus far obtained in controlled studies on a series of patients with UC did not result in the desired beneficial effects (30).

The therapeutic armamentarium for $\mathrm{CD}$ has notably expanded in the last few years, particularly with the contribution of the so-called biologic therapies, whose one and only representative for $\mathrm{CD}$ is currently infliximab. These therapies effectively heal the inflamed intestinal mucosa, close associated fistulas, and notably modify the disease clinical course.

Novel molecules such as CDP-571, CDP-870, alpha-4 integrin, ICAM-1, CNI1493 , and so on are being studied -some of them already in phase-2 or -3 trials; they have demonstrated an outright efficacy in preclinical studies so far.

New studies to adequately identify the presence of response predictive factors for these new biologic therapies are clearly needed, so that they may be more appropriately administered to rigorously selected patients.

In the near future we may likely tailor CD therapy based on the genetic, clinical, biochemical, and serologic profile of each patient suffering from this complex disease.

L. Rodrigo Sáez Service of Digestive Diseases. Hospital Central de Asturias. Oviedo

\section{References}

1. Van Dullemen HM, Van Deventer SJH, Hommes DW, et al. Treatment of Crohn's disease with anti-tumor necrosis factor chimeric monoclonal antibody (cA2). Gastroenterology 1995; 109: 129-35.

2. Sandborn WJ, Hanener SN. Antitumor necrosis factor therapy for inflammatory bowel disease. A review of agents, pharmacology, results and safety. Inflamm Bowel Dis 1999; 5: 119-33. 
3. Regueiro M. Update in medical treatment of Crohn's disease. J Clin Gastroenterol 2000; 31: 282-91.

4. Dubinsky MC, Lamothe S, Yong Yong H, et al. Pharmacogenomics and metabolite measurement for 6-mercaptopurine therapy in inflamatory bowel disease. Am J Gastroenterol 2000; 118: 705-13.

5. D'Haens G, Geboes K, Rutgeerts P. Endoscopic and histologic healing of Crohn's ileo-colitis with azathioprine. Gastrointest Endosc 1999; 50: 667-71.

6. Feagan B, Fedorak R, Inine E, et al. A comparison of methotrexate with placebo for the maintenance of remission in Crohn's disease. N Engl J Med 2000; 342: 1.627-32.

7. Targan SR, Hanauer SB, Van Deventer SJH, et al. A short-term study of chimeric monoclonal antibody cA2 to tumor necrosis factor for Crohn's disease. N Engl J Med 1997; 337: 1029-35.

8. Present DH, Rutgeers P, Targan SR, et al. Infliximab for the treatment of fistulas in patients with Crohn's disease N Engl J Med 1999; 340; 1398-405.

9. Rutgeers P, D'Haens G, Targan SR, et al. Efficacy and safety of retreatment with anti-tumor necrosis factor antibody (Infliximab) to maintain remission in Crohn's disease. Gastroenterology 1999; 117: 761-9.

10. Hanauer SB, Feagan BG, Lichtenstein GR, et al. Maintenance infliximab for Crohn's disease: the ACCENT I randomised trial. Lancet 2002; 359: 1541-9.

11. D'Haens G, Van Deventer S, Van Hogezand R, et al. Endoscopic and histological healing with infliximab anti-tumor necrosis factor antibodies in Crohn's disease: A. European multicenter trial. Gastroenterology 1999; 116: 1029-34.

12. Lügering A, Schmidt $M$, Lügering $N$, et al. Infliximab induces apoptosis in monocytes from patients with chronic active Crohn's disease by using a caspase-dependent pathway. Gastroenterology 2011; 121: 1145-57.

13. Ten Hove T, Van Montfrans C, Peppelenbosch MP, et al. Infliximab treatment induces apoptosis of lamina propia T lymphocytes in Crohn's disease. Gut 2002; 50: 206-11.

14. Van den Brande JMH, Braat H, Van den Brink GR, et al Infliximab but not etanercept induces apoptosis in lamina propia T lymphocytes from patients with Crohn's disease. Gastroenterology 2003; 124: 1774-85.

15. Louis E, Vermeire S, Rutgeers P, et al. A positive response to infliximab in Crohn's disease: association with a higher systemic inflammation before treatment but not with - 308 TNF gene polymorphism. Scand J Gastroenterol 2002; 37: 818-24.

16. Parsi MA, Achkar JP, Richardson S, et al. Predictors of responde to infliximab in patients with Crohn's disease. Gastroenterology 2002; 123: 707-13

17. Vermeire S, Louis E, Carbonez A, et al. Logistic regression of clinical parameters influencing responde to infliximab. Am J Gastroenterol 2002; 97: 2.357-63.

18. Luna-Chadid M, Pérez Calle JL, Mendoza JL, et al. Factores predictivos de respuesta a infliximab en pacientes con enfermedad de Crohn fistulizante. Rev Esp Enferm Dig 2004; 96: 379-84.

19. Gregor JC, Mc Donald JWD, Kler N, et al. An evaluation of utility measurement in Crohn's disease. Inflamm Bowel Dis. 1997; 3: 265-76.

20. Lichtenstein GR, Bala M, Han C, et al. Infliximab improves quality of life in patients with Crohn's disease. Inflamm Bowel Dis 2002; 8: 237-43.

21. Feagan BG, Yans, Bala M, Bao W. Lichtenstein GR. The effects of infliximab maintenance therapy on health related quality of life. Am J Gastroenterol 2003; 98: 2232-8.

22. Cadahia V, García-Carbonero A, Vivas S, et al. Inflixiamb mejora la calidad de vida en pacientes con enfermedad de Crohn fistulosa. Rev Esp Enferm Digest 2004; 96: 369-78.

23. Baert F, Noman M, Vermeire S, et al. Influence of immunogenicity on the long-term efficacy of infliximab in Crohn's disease. N Engl J Med 2003; 348: 601-8.

24. Farrell RJ, Alsahli M, Jeen YT, et al. Intravenous hydrocortisone premedication reduces antibodies to infliximab in Crohn's disease: A randomized controlled trial. Gastroenterology 2003; 124: 917-24.

25. Crandall WV, Mackner LM. Infusion reactions to infliximab in children and adolescents, frequency, outcome and a predictive model. Aliment Pharmacol Ther 2003; 17: 75-84.

26. Keane J, Gershon Sh, Wise RP, et al. Tuberculosis associated with infliximab, a tumor necrosis factor $\alpha$-neutralizing agent. N Engl J Med 2001; 345: 1.098-104.

27. Gomez-Reino JJ, Carmona L, Valverde VR, et al. Biobadaser Group. Treatment of rheumatoid arthritis with tumor necrosis factor inhibitors may predispose to significant increase in tuberculosis risk: a multicenter active-surveillance report. Arthritis Rheum 2003; 48: 2085-91.

28. Colombel JF, Loftus EVJr, Tremaine WJ, et al. The safety profile of infliximab in patients with Crohn's disease. The Mayo clinic experience in 500 patients. Gastroenterology 2004; 126: 19-31.

29. Regueiro M, Valentine J, Plevy S, et al. Infliximab for treatment of pyoderma gangrenosum associated with inflammatory bowel disease. Am J Gastroenterol 2003; 98: 1821-6.

30. Probert CSJ, Hearing SD, Schreiber S, et al. Infliximab in moderately severe glucocorticoid resistant ulcerative colitis: a randomised controlled trial. Gut 2003; 52: 998-1002. 


\section{Infliximab en la enfermedad de Crohn}

El infliximab (IFX), es un anticuerpo monoclonal quimérico (humano-75\% /ratón-25\%) de la clase IgG-1, preparado para bloquear de forma específica los receptores celulares, así como el TNF- $\alpha$ circulante, citoquina de respuesta tipo TH-1, que posee una intensa acción pro-inflamatoria. La administracion del IFX (Remica$\mathrm{de}^{\circledast}$, Centocor, Malvern, PA; Schering-Plough, Kenilworth NJ, USA), una nueva terapia biológica, produce por tanto en el individuo al que se le administra, un marcado y potente efecto terapéutico, de tipo fundamentalmente antiinflamatorio (1).

Las dos indicaciones claramente establecidas para su utilización en la enfermedad de Crohn (EC), son para el tratamiento de los brotes inflamatorios de intensidad moderada o severa y en los pacientes que presentan fístulas asociadas, y su utilización en la clínica fue aprobada por la FDA americana, en octubre de 1998 y desde entonces su empleo se ha generalizado de forma notable, en todo el mundo $(2,3)$. No está indicada su utilización en presencia de estenosis fibrosa (contraindicación relativa) y no se debe emplear (de forma absoluta) en pacientes con infección asociada extra-intestinal de diversos orígenes (bacteriana, viral o fúngica) y de cualquier localización.

Para el tratamiento de la EC se vienen utilizando en la practica clínica diversos medicamentos, tanto en las fases de agudización de la enfermedad, como en los periodos de mantenimiento, para la prevención de la aparición de brotes de recidiva.

Los fármacos considerados de primera elección en la EC, como son la sulfasalazina, los aminosalicililatos y los corticoides, se utilizan tanto en la fase de agudización como para la prevención de recidivas. Cuando el paciente no responde a este tipo de medicamentos o bien se establece una situación de córtico-dependencia o córtico-refractariedad, se opta por cambiar la medicación, eligiendo entonces los fármacos inmunomoduladores, como segundo escalón terapéutico a largo plazo.

Entre los medicamentos de este segundo grupo, los más utilizados son la azatioprina (AZA), o su metabolito directo, la 6-mercaptopurina (6-MP) y el metrotexate (MTX), que tradicionalmente se venían utilizando en la prevención del rechazo de órganos sólidos en pacientes trasplantados, así como en el control de pacientes con enfermedades articulares de base autoinmune, como la artritis reumatoide (AR) y la espondilitis anquilosante (EA).

Tanto en la EC, como en la colitis ulcerosa (CU), los fármacos inmunosupresores han demostrado por lo general, una elevada eficacia clínica, un buen perfil de seguridad y una excelente efectividad, en términos de coste/beneficio (4-6).

La llegada del infliximab (IFX) al arsenal terapéutico, como un tercer escalón para controlar la EC, ha supuesto un cambio significativo, ya que consigue disminuir por un lado la inflamación intestinal de forma rápida y eficaz y por otro, se trata del primer tratamiento médico que ha conseguido el cierre de las fístulas asociadas con la enfermedad de forma persistente, en un porcentaje elevado de pacientes, que se sitúa en torno al $60 \%$ de los casos. 
El primer ensayo clínico controlado con IFX, fue publicado por Targan y cols. en 1997, en pacientes con EC inflamatoria en brote moderado a severo y mostró una respuesta inicial a las 4 semanas del $81 \%$, después de una única infusión intravenosa de $5 \mathrm{mg} / \mathrm{kg}$ de peso, frente a un $17 \%$ en el grupo placebo. La remisión clínica se consiguió en el $33 \%$ de los pacientes tratados, frente al $4 \%$ de los que recibieron placebo. Una pequeña proporción de pacientes que no respondieron a la infusión inicial, lo hicieron cuando recibieron una segunda dosis, al cabo de 4 semanas (7).

En el tratamiento de la EC complicada con fístulas con IFX, en las que se administran tres infusiones intravenosas a la dosis de $5 \mathrm{mg} / \mathrm{kg}$, en las semanas 0,2 y 6 , en el estudio realizado por Present y cols. (8) en el que se incluyó un total de 98 pacientes, encontraron una respuesta al tratamiento con IFX del $62 \%$ frente a un $26 \%$ de los tratados con placebo. De los pacientes tratados, un 55\% presentaron cierre completo de las fístulas, frente a un $13 \%$ de los asignados al grupo placebo $(\mathrm{p}=0,001)$.

Después del entusiasmo generado tras el conocimiento de los resultados obtenidos en los estudios iniciales, se observó que una gran parte de los pacientes tratados, recaían al cabo de 8-12 semanas después de finalizado un primer ciclo de tratamiento. Por el contrario, si estos pacientes recibían dosis de recuerdo con IFX cada ocho semanas, se prolongada el beneficio clínico alcanzado de forma significativa (9).

Estos resultados fueron confirmados por el estudio ACCENT I, que es el trabajo publicado, que por el momento, presenta una mayor serie de pacientes en tratamiento de mantenimiento con IFX (10). En este estudio se incluyeron un total de 573 pacientes con EC activa a los que se les administró una infusión inicial de IFX. En la $2^{a}$ semana, el $58 \%$ de los pacientes mostraron una respuesta clínica. Los pacientes respondedores fueron posteriormente asignados a tres grupos de tratamiento durante 54 semanas. Un grupo control con placebo, otro con IFX a la dosis de $5 \mathrm{mg} / \mathrm{kg}$ y un tercero a la dosis de $10 \mathrm{mg} / \mathrm{kg}$ administrados por infusión endovenosa cada 8 semanas. De los pacientes tratados con IFX a la dosis de $5 \mathrm{mg} / \mathrm{kg}$, aproximadamente un $50 \%$ mantenían una respuesta clínica a la semana 30 y un 35\% a la semana 54. Los que recibieron $10 \mathrm{mg} / \mathrm{kg}$ no presentaron una mejor respuesta que los tratados con 5 $\mathrm{mg} / \mathrm{kg}$.

En este como en otros estudios se ha comprobado reiteradamente que el IFX es capaz de inducir una disminución muy importante, prácticamente completa, de las lesiones inflamatorias del intestino, comprobadas tanto endoscópica, como histológicamente (11).

En cuanto al mecanismo de acción, el IFX bloquea tanto el TNF soluble (TNFs) circulante, como el ligado a la membrana celular (TNF-m) y es capaz de inducir apoptosis (muerte celular programada) a nivel de los monocitos de sangre periférica mediante la vía de activación de las caspasas, tanto en pacientes con EC como en individuos sanos. De la misma manera la administración del IFX produce apoptosis de los linfocitos T (CD-4+) situados a nivel de la lámina propia intestinal $(12,13)$.

Los efectos del IFX son probablemente diferentes en la AR que en la EC, ya que en aquella, la neutralización del TNF soluble es su principal mecanismo acción, mientras que en la EC este efecto no es suficiente, ya que la apoptosis de los linfocitos localizados a nivel de la lámina propia intestinal se considera de importancia fundamental para llevar a cabo su efecto terapéutico. Ello explica que la administración del Etanercept, otro anticuerpo monoclonal anti-TNF, resulte eficaz en la AR porque neutraliza el TNF-s, pero su empleo no está indicado en la EC, ya que no es capaz de bloquear los receptores del TNF-m (14). 
Se han llevado a cabo varios intentos para tratar de explicar por un lado la falta de respuesta al IFX, que se produce en un $20-30 \%$ de pacientes, así como para intentar buscar la existencia de posibles factores predictivos de respuesta, especialmente en paciente con EC fistulosa.

Louis y cols. (15) demostraron que la respuesta al tratamiento con IFX se asociaba con la presencia de un mayor grado de inflamación sistémica, medido de forma indirecta a través de la elevación de la proteína $\mathrm{C}$ reactiva (PCR). Así en un estudio realizado sobre 226 pacientes con EC, la respuesta fue superior en pacientes con PCR elevada ( $>5 \mathrm{mg} / \mathrm{l})$ que en los que la tenían normal (76 frente a un $46 \%, p=0,004$, OR: 0,26$)$ y no lo encontraron relacionado con los polimorfismos genéticos del TNF, tales como la variante -308A, o alta productora de TNF.

El único factor predictivo claro de respuesta comunicado hasta el momento, ha sido el empleo concomitante de inmunosupresores tales como la AZA, 6-MP y el $\operatorname{MTX}(16,17)$.

En el presente número de la revista, Luna-Chadod y cols. analizaron una serie de factores predictivos de respuesta, en una serie de 108 pacientes con EC fistulizante, en un estudio multicéntrico, llevado a cabo en siete hospitales de la comunidad de Madrid y no encuentran ningún factor significativo asociado, al igual que ha ocurrido en diversos estudios publicados previamente sobre este tema (18).

La calidad de vida de los paciente con EC se encuentra bastante alterada, tanto a nivel físico como en las funciones psicológicas y su grado de disfunción es importante, tanto aisladamente, como cuando se le compara con otras enfermedades crónicas. Así Gregor y cols. encontraron que la medición de los parámetros de calidad de vida relacionados con la salud (CVRS) en pacientes con EC controlada, era muy similar a la que presentan los pacientes con una angina de pecho de grado severo, que se acompaña de una importante incapacidad laboral (19).

Se han realizado diversos estudios sobre el efecto que ejerce el IFX en la CVRS en pacientes con EC, demostrando claramente su eficacia, tanto en el tratamiento agudo, como en el de mantenimiento a largo plazo $(20,21)$.

En este número de la revista, Cadahia y cols. estudian la mejoría efectuada a corto plazo por el IFX, en una serie de 25 pacientes con EC fistulosa, empleando dos tipos de tests, uno general (el SF-36) y otro específico (el IBDQ) que los comparan con el índice de actividad clínica (CDAI), realizados a lo largo del tratamiento agudo y un mes después de finalizado este. Al igual que otros autores encuentran una mejoría significativa en los parámetros que evalúan la función física y la actividad de la enfermedad, no encontrando cambios llamativos en la función social que, a diferencia de la anterior, se encuentra mejor conservada (22).

Las reacciones a la infusión con IFX se piensa que aparecen como consecuencia del desarrollo de anticuerpos anti-infliximab (ATI) y son una complicación bien conocida, evaluando su incidencia entre el 13-18\% de los pacientes tratados. Pueden ser tanto precoces, como tardías. Entre las inmediatas, las más frecuentes consisten en síntomas leves, tales como la aparición de enrojecimiento facial, hasta otras importantes de tipo anafiláctico, con la instauración de cuadros de disnea e hipotensión arterial. La disminución del ritmo de la infusión es, en la mayor parte de los casos, suficiente para tratar estos procesos y se pueden completar las infusiones, a pesar de haber aparecido la reacción, cuando son leves y pasajeras.

El desarrollo de ATI se asocia por una parte, con la aparición más frecuente de reacciones a la infusión en dosis sucesivas y por otra, con una reducción en el índice de respuesta al tratamiento con IFX. Se ha sugerido que el tratamiento concomitante con inmunosupresores, la administración previa a la infusión de una dosis de 
hidrocortisona por vía intravenosa y acortar el intervalo de tiempo transcurrido entre las infusiones, pueden disminuir de forma notable, tanto la frecuencia como la intensidad de las reacciones alérgicas secundarias a su administración $(23,24)$.

Las reacciones tardías a la infusión más frecuentes consisten en la aparición de dolor e hinchazón a nivel de diferentes articulaciones, que se tratan habitualmente con la administración de AINE y/o corticoides. La frecuencia de aparición de reacciones a la infusión con IFX, tanto precoces como tardías, es similar en adultos y niños (25).

En cuanto a la aparición de efectos adversos infecciosos, uno muy importante y bien conocido, es la tuberculosis. En una revisión efectuada sobre datos aportados por la FDA americana, sobre un total de 150.000 pacientes tratados con IFX hasta el 29 de mayo del 2001, habían aparecido un total 70 casos de tuberculosis, con una media de 12 semanas de tratamiento, 40 de los cuales presentaban afectación extrapulmonar, tratándose en la mayoría de los casos, de reactivaciones de una enfermedad latente, previamente existente (26).

En una revisión recientemente publicada en nuestro país efectuada bajo los auspicios de la Sociedad Española de Reumatología, en la que participaron un total de 71 centros comunicaron una incidencia estimada de 1,9 por $10^{5}$ en el año 2000 , que descendió a 1,1 por $10^{5}$ en el 2001. Desde la adopción de medidas de despistaje sistemático de Tbc. previo al tratamiento con IFX (realización rutinaria de placa de tórax y prueba de PPD), la incidencia disminuyó notablemente habiendo sido encontrado un solo caso en los 5 primeros meses del 2002, en el estudio publicado por Gomez Reino y cols. (27).

El perfil de seguridad del IFX ha sido cuidadosamente analizado en una extensa serie de 500 pacientes con EC tratados en la Clínica Mayo, que habían recibido una media de tres infusiones por paciente, con un seguimiento medio de al menos 17 meses. El 6\% de los pacientes tratados con este régimen presentaron un efecto secundario importante y entre ellos los más frecuentes fueron los episodios infecciosos agudos. Por lo tanto, los clínicos que tratan estos pacientes con este tipo de fármacos, deben vigilarlos estrechamente para detectar precozmente y prevenir la aparición de posibles complicaciones, tanto de tipo infeccioso, como reacciones a su administración y posibles alteraciones de tipo autoinmune (28).

En cuanto a la aparición de posibles neoplasias relacionadas con la toma del IFX, se desconoce si la administración a largo plazo con esta nueva terapia biológica es capaz de provocar un aumento en la incidencia de estos procesos malignos, tanto linfomas como tumores sólidos, por sus efectos inmunosupresores aumentados con el empleo simultáneo de otros fármacos (AZT o MTX), pero por el momento no parece estar incrementada y existe una amplia experiencia acumulada con la utilización del IFX, ya que a finales del 2002 se estimaba que habían sido tratados alrededor de 340.000 pacientes en todo el mundo.

Otras indicaciones del tratamiento con IFX son las complicaciones sistémicas relacionadas con la EC. Así en una serie de 13 pacientes que presentaron pioderma gangrenoso de grado moderado a severo, su administración produjo una completa cicatrización de las lesiones cutáneas en todos los pacientes (29).

Sin embargo, no parece que la administración del IFX vaya ampliarse al tratamiento de pacientes con colitis ulcerosa (CU), ya que los resultados obtenidos por el momento en estudios controlados realizados en una serie de pacientes con $\mathrm{CU}$, no han producido los efectos beneficiosos deseados (30).

El arsenal terapéutico de la EC se ha expandido notablemente en los últimos años y a ello han contribuido muy especialmente, la llegada de los llamados trata- 
mientos biológicos cuyo principal y único representante por el momento, es el infliximab. Estos tratamientos han conseguido de forma eficaz cicatrizar la mucosa intestinal inflamada, cerrar las fístulas asociadas y modificar de forma notable el curso clínico de la enfermedad.

Se están estudiando nuevas moléculas como CDP-571, CDP-870, alfa-4 integrina, ICAM-1, CNI-1.493 y otras, algunas de las cuales se encuentran en fases 2 y 3 de su investigación, habiendo mostrado una clara eficacia en estudios preclínicos realizados hasta la actualidad.

Claramente se necesita disponer de nuevos estudios que sean capaces de identificar adecuadamente la presencia de factores predictivos de respuesta para estas nuevas terapias biológicas, que permitan aplicarlos de una forma más adecuada en pacientes rigurosamente seleccionados.

En un futuro próximo, probablemente podamos llevar a cabo un tratamiento individualizado de la EC, basado en el perfil genético, clínico, bioquímico y serológico de cada uno de los pacientes afectados por esta compleja enfermedad.

L. Rodrigo Sáez Servicio de Aparato Digestivo. Hospital Central de Asturias. Oviedo 